\title{
Accounting Window Dressing and Template Regulation: A Case Study of the Australian Credit Union Industry
}

\author{
David Hillier \\ *Allan Hodgson \\ Peta Stevenson-Clarke \\ Suntharee Lhaopadchan
}

JEL Classification: G21, M40

Keywords: Cooperative Stakeholder Governance; Capital Adequacy Regulation; Accounting Window Dressing

\begin{abstract}
This paper highlights the response of cooperative institutions that are required to adhere to new capital adequacy regulation traditionally geared for profit-maximizing organizations. Using data from the Australian credit union industry, we demonstrate that the cooperative philosophy and internal corporate governance structure of cooperatives will lead management to increase capital adequacy ratios through the application of accounting window dressing techniques. This is opposite to the intended purpose of template regulation aimed at efficiently increasing operating margins and lowering risk. Our results raise several debatable issues regarding the ethics of accounting management and the imposition of one-shoe-fits-all external regulation.
\end{abstract}

We would like to thank the anonymous referees, Christine Brown, Kevin Davis, Marc DeCeuster, Kevin Keasey, Chris Humphreys, Gordon Richardson, Don Stokes and seminar participants at the Universities of Strathclyde, Manchester, Leeds, Newcastle (NSW), Queensland University of Technology, University College Dublin, and participants at the 2004 European Risk Management Conference and 2005 European Financial Management Symposium for comments and feedback. All errors remain our own. 


\section{Introduction}

This paper documents the actions that Australian credit unions took to mitigate the impact of, what is arguably, inappropriate legislation. The reactions and context provide a rich basis for discussion of the ethics of accounting window dressing. The widespread adoption of template capital adequacy regulation through the Basel Accords of the Bank of International Settlements (BIS), has centered concern on its effect on bank and managerial performance (REF). However, there is very little discussion on whether template regulation geared primarily for profit-maximizing organizations is an appropriate policy for financial institutions, such as cooperatives, with fundamentally different objectives. Credit unions, which are a particular form of cooperative, are run for the benefit of both depositor and borrower members with any profits minimized through the balancing of appropriate deposit and lending rates. Hence, given that the major stated purpose of capital adequacy regulation is to protect shareholders from excessively risky profit-making activities, it is important to analyze the impact of the regulatory extension to non-profit making institutions.

Credit union managers can respond in two main ways to enhanced capital adequacy restrictions. One, they may improve their capital reserves to acceptable levels by widening operating margins through increased lending and/or decreased deposit rates, or by taking steps to reduce operating costs. However, these options are unlikely to be popular with directors and members because at least one group would be forced to carry the major part of the cost burden, in conflict with long standing cooperative principles. Alternatively, managers could undertake some form of window dressing by manipulating their accounting ratios without changing business policy. This would have little impact on the endogenous allocation of member services and would, if successful, lower censure threats to entrenched management and allow time for managers to adjust operations in a more measured fashion.

The ethics and reaction to regulatory compliance has previously been examined with regard to its effect on managerial or agent behavior [see, for example, Harcourt and Harcourt (2002), Moore (2004), Canary and Jennings (2007), Criado-Jiminez, Fernandez-Chulian, Husillos-Carques, and Larrinaga-Gonzalez (2007)]. In addition, research on the ethics of earnings management, has focused on the role of corporate social responsibility [Chih, Shen, and Hang (2007)], the views of employees who know that colleagues are engaging in earnings management [Kaplan, McElroy, Ravenscroft, and Shrader (2007)], the effect of the Sarbanes-Oxley Act (2001) on misleading 
reporting activity in firms [Entwistle, Feltham, and Mbagwu (2006)], and the micro and macro features of creative accounting [Gowthorpe and Amat (2005)]. In this article we combine the interaction between template regulation, internal governance structures and accounting window dressing in credit union cooperatives in order to present an empirical and philosophical platform to debate the ethics of accounting management.

The specific case we use is the imposition of the 1992 Australian Financial Institutions Code (AFIC) on credit unions in New South Wales, Australia. AFIC is particularly interesting because, for the very first time, credit unions with their cooperative operating principles were governed by the capital adequacy rules of the 1988 Basle Accord, which is primarily targeted at large international banks with access to a large shareholder equity base. The major effect of AFIC was that credit unions with capital ratios below the stated minimum of $8 \%$ were forced to meet this level within a maximum period of three years and faced regulatory censure and loss of operational control in the meantime. This was imposed despite the fact that cooperatives essentially have no access to external equity and are not driven by profit seeking behaviour.

Our empirical results show that managers of at-risk credit unions (capital ratios below 8\%) engaged in accounting window dressing rather than implementing efficiency improvements to meet required capital reserves. In particular, the most common approach involved reclassifying assets on the balance sheet to gain the appearance that capital ratios were improving, when in fact the business strategy remained relatively unchanged. This raises several issues regarding the use of template external regulation and accounting window dressing to counteract philosophical, agency and personal impacts. First, is it appropriate to impose template external regulation on institutions far removed from the original purpose? Second, should cooperatives utilize accounting window dressing and other manipulations to maintain the extended stakeholder philosophy? Third, is the response by credit union managers justified given subsequent longer term outcomes?

The remainder of this paper is structured as follows. The next section describes the salient governance features of credit unions and the institutional aspects of the Australian Financial Institutions Code. Section three develops the hypotheses, section four describes the data, and section five introduces the econometric model and reports our empirical results. Finally, section six contains our conclusions and discusses several ethical issues. 


\section{Institutional Background}

\subsection{Credit union structure and philosophy}

Credit unions, with antecedents, philosophies and operating procedures that vary significantly from other financial and banking intermediaries, have several unique agency relationships. Their philosophy is developed from mutual collaboration, with the main purpose to provide services to members at cost, the equitable treatment of members, and a broad notion of community service to an extended stakeholder set based on co-operative principles [see for example Smith, Cargill and Meyer (1980), Smith $(1984,1988)$ and Davis (2001)]. This approach is reflected in their modus of operations, which is founded on a one member-one vote basis. Member borrowers and savers are treated equally with the view that there be no conflict between these two classes of members. Further, credit unions traditionally draw membership from narrow restrictive bonds, usually based on geographical boundaries and common occupational employment or associations [Frame, Karels and McClatchey (2002)]. Their main focus is on providing credit in the form of personal unsecured loans, more difficult to obtain from banks and significantly less expensive than from other financial institution sources. The unique relationship between members and the credit union allows default risk to be minimized through payroll deduction schemes, a strong personal agency relationship, and customer focused banking. ${ }^{1}$

There are other agency relationships that arise due to the institutional structure of credit unions. Davis (1994) documents that credit unions have unrefined corporate governance structures with policy and board agenda dominated by managers. As a result, there are moral hazard problems that results in weak bonding covenants between management, the membership, and the board of directors. First, there is weak governance by members. Because of the one member-one vote policy, the incentive and ability of members to generate a concentration of voting power is limited and member attendance and voting at general meetings is very low. ${ }^{2}$ Second, there is weak board governance. Board directors are often internally or politically appointed with limited outside independent board members. More often they are volunteers, not remunerated, frequently drawn

\footnotetext{
1 "The fact that such small, ostensibly cooperative organisations, can manage to survive (even thrive) is a reflection of their distinctive organisational cultures which appear to produce satisfied and loyal customers who are prepared to pay a premium price for loans and yet who are staunch and loyal advocates." (Duncan and Elliot 2002, p.23). ${ }^{1}$

${ }^{2}$ The Credit Union National Association (1999) stated that voter turnout for small credit unions was only $26.1 \%$ whereas for large credit unions, it was even lower at $6.2 \%$.
} 
from a narrow employment bond and, therefore, lack skills related to the management and monitoring of a financial institution. However, whilst generally lacking financial skills, board members bring to the table a strong co-operative esprit de corps.

Third, a combination of extended stakeholder and cooperative principles, gives rise to internal management that has a strong bond with employees as an extension of the cooperative stakeholder group. In this way managers obtain a potentially large and influential voting block. As early as Berle and Means (1932) there was a recognition that, in the face of diffused member and board power, managers may further their own interests by hiding poor performance, diverting cashflow to preferred investments, giving themselves overly generous salary and perquisites, and in capitalising these benefits by job entrenchment. Davis (1994) and Frame, Karels and McClatchey (2003) suggest this may be the case for some credit union managers.

In summary, the corporate governance system of credit unions is significantly different from profit seeking financial institutions because they do not conform to the standard principalagent model [Keasey, Thompson and Wright (2004)]. Instead, they have a dual governance system that reflects a weak principal-agent relationship between members, the board of directors and the general manager, but with a strong cooperative-extended stakeholder view of the world. This distinction is particularly interesting given that financial co-operatives must compete with banks, whose internal governance is more closely aligned to a Jensen and Meckling (1976) shareholder principal-agent perspective.

\subsection{The 1992 Australian Financial Institutions Code}

In July 1992, the Australian Financial Institutions Code (AFIC) was introduced to provide template prudential regulation for all Australian financial co-operative societies. ${ }^{3}$ The AFIC prudential requirements emulated the minimum risk-weighted capital ratios of the first Basle Accord (Table 1 details the risk weighting of assets). Market, credit data and operations risk are required to be managed and reported together with the provision of guarantees, management contracts, and funds under external management. The stated primary objectives of the AFIC legislation are: (i) to protect and promote financial integrity and efficiency, and (ii) to protect the interests of depositors.

INSERT TABLE 1 ABOUT HERE

\footnotetext{
${ }^{3}$ The codes encompass permanent building societies and credit unions.
} 
Given the restriction on credit union markets implied by their common bonds, they can be subject to significant shifts in the demand for loans or supply of funds caused by income and demographic changes in membership. These factors, in conjunction with small size diseconomies, mean they have higher overall risk management problems in the form of exposed liquidity and interest rate risk [Goldsworthy, Schulz and Shuetrim (2000)]. The proposals for the AFIC regulatory reform of the Australian cooperative financial sector was based on perceptions of higher relative risk structures compared to banks, with the sanctions intended to encourage the rehabilitation of undercapitalised institutions.

Credit union prudential standards are backed by the force of law under the AFIC Code. The penalties for falling below minimum capital requirements include sanctions on loan portfolios and investment activities, monitoring of activities, increased reporting requirements, the placing of credit unions under direction (with an outside manager gaining control), or even forced merger. Any of these sanctions would result in the loss of managerial and board reputation and possible dismissal of the manager. Hence, it is costly for managers to violate and remain below minimum capital requirements set out under AFIC. Prior to AFIC, financial co-operatives were regulated by a range of legislation that differed across Australian states. Important to our study is the fact that the New South Wales co-operative legislation required a significantly lower minimum capital ratio of 3\% immediately prior to AFIC and therefore urgent action was required by some credit unions.

\section{Hypotheses Development}

The abrupt imposition of prudential standards under AFIC has several implications if credit unions are in breach: (i) they restrict the ability of credit unions to maintain an extended stakeholder philosophy, (ii) they impose high potential costs on credit union members, (iii) managers would suffer personal reputation impairment and human capital loss, and (iv) may force credit unions to merge with a loss of identity. Therefore, we predict that at-risk credit unions will significantly increase the capital adequacy ratio at or around the introduction of AFIC effective the July 1992 quarter. However, we also predict this will be achieved without any significant change in operations that will affect the 'special relationship banking' that credit unions have with their members. These contentions are consistent with Kane's description of 'regulatory dialectic' in which regulation is followed by avoidance behaviour on the part of regulated firms and with the empirical research in 
the banking literature [see Beatty, Chamberlain and Maglioli (1995), Collins, Shackelford and Whalen (1995)].

This avoidance behaviour is also accentuated by the restrictive manner in which credit unions can increase risk weighted capital. As cooperatives they cannot raise external equity to satisfy any sudden changes in regulatory capital requirements, such as banks are able to do. Capital is restricted to one share per member and these cannot be exchanged or traded. Thus, risk weighted capital can only be quickly accumulated through retained profits obtained from operating activities, a radical change in the loan portfolio, or window dressing by the use of manipulative accounting techniques. We predict that the constraints imposed by cooperative philosophies together with internal power issues, will incentivize the use of accounting manipulations over improved profitability to increase risk weighted capital. The theoretical bases for our hypotheses are further developed below.

\subsection{Profitability}

In AFIC there is a presumption that regulation will promote efficiency and this will be reflected in increased profitability as a surrogate. This is backed by regulatory sanctions determined by the level of risk weighted capital, which is predicated on the normative belief that efficient behavioural changes can be imposed on under-capitalised cooperatives in such a way so as to reduce inherent risk factors with a simultaneous reduction in losses to depositors. The AFIC prudential reforms therefore emphasise the pre-eminent role for risk capital in the regulatory process. Activities deemed to be higher risk require a larger backing of capital, ${ }^{4}$ which in turn implies that the risk of those activities is borne by equity-holders rather than depositors, reflecting the philosophy generated by the Basle Accord.

However, profit maximising behaviour is incompatible with a co-operative philosophy. Smith, Cargill and Meyer (1981) highlight two major factors affecting the objectives of a credit union: (i) the value of a credit union should be maximised with respect to both borrower and depositor, and (ii) any probability of conflict arising between borrowers and depositors should be

\footnotetext{
${ }^{4}$ For example, a credit union with assets of A $\$ 1.0$ million, comprised of only business and personal loans (with a risk weighting of 1.0), would be required to have $A \$ 80,000$ in capital in order to meet the $8 \%$ requirement. On the other hand, if the same credit union had assets comprised of residential mortgage loans (with a risk weighting of 0.5$)$, then only A $\$ 40,000$ of equity capital would be required.
} 
minimised. Thus, the accrual of capital from members through operating profits poses a serious philosophical problem for management. Increasing profits impose direct costs on members (by increasing the operating margin) and decisions have to be made as to whether the costs are borne by member depositors, member borrowers, or shared in some manner.

There are also implicit cross-subsidies in such capital creation. Whilst current members receive the benefits provided by capital reserves that accrued at the expense of past members, they in turn bear the costs of current surpluses, which are then retained for the benefit of future members. If capital accrues at a constant rate then the intertemporal burden on members is shared evenly. However, current members who are forced to bear sudden and large jumps in capital creation will 'over-subsidise' future members without any return for these costs. Besides these considerations, there are pragmatic reasons for not altering current deposit and loan rates. Credit unions must compete in the mature banking industry and any change in rates risks a flight of current members, not willing to subsidise future members, to other financial service providers. As a result, managers are unlikely to discriminate against any class of members in order to increase profitability.

Another way to increase profitability is to cut operating costs. The major costs faced by financial service providers, other than interest expense, is salaries. In credit unions, during the period of this study, the average cost of salary as a proportion of total expenses was $16 \%$ compared to $10 \%$ for the four largest credit unions. The difference of $6 \%$ reflects the higher investment that credit unions have in staff focused on relationship banking. The evidence is that this builds a high level of quality customer service [Colgate and Lang (2005)], provides a sustained competitive advantage [Duncan and Elliot (2002)], and higher relative financial returns [Allred (2001), Allred and Adams (2000)]. If this is the case then managers would not rationally cut these expenditures. Finally, managers could turn to other expenses to cut costs but the empirical evidence for banks suggests that efficiency gains through cost cutting is not an easy short-term recovery path [Dahl and Spivey (1995)]. Hence, we predict that profitability is unlikely to be increased by the endorsement in a reduction of the above costs by managers or boards. This leads to our first hypothesis:

H1: At-risk credit union managers will not implement policies designed to increase operating efficiency and raw profitability in order to meet the minimum capital requirements imposed by the introduction of capital adequacy regulation. 


\subsection{Accounting Window Dressing}

In the above section we argue that the cooperative extended-shareholder philosophy will inhibit the proclivity of managers to increase profitability (and capital) by cost cutting or changing operating margins. Another strategy to increase required risk weighted capital is to window dress by the use of accounting manipulations. At-risk credit union managers could potentially use a portfolio of three basic accounting techniques. Two approaches that directly address the numerator in the risk weighted regulatory capital ratio have been widely covered - the use of discretionary accounting and dirty surplus accounting. We examine the extent that all available unexpected accruals, including bad debts, long service and holiday leave expense; together with the impact that dirty surplus accounting adjustments - asset revaluations, extraordinary items, and loan loss provisions - directly affect the numerator. We also extend previous studies by examining the denominator and our third potential accounting management technique is to reclassify the risk weighting of assets into a lower risk class. These accounting reclassifications are risky and would only be attempted if managers were highly motivated to do so or were able to justify the legitimacy of their actions to the legislating authorities.

We argue, from a moral point of view, that it was within the rights and duties of managers to use their professional judgment to undertake actions that circumvented the inadvertent impacts of template regulation in order to maintain the credit unions charter. The first issue is that the measure of risk applied to credit union personal loans, their main source of income during the period, ${ }^{5}$ is inappropriate. It is well known that credit unions have a comparative advantage in managing personal loan debt. Because of their restrictive membership covenants, and relationship banking philosophy, they have lower agency costs and thus bad debts when compared to banks [Davis (1994)]. Therefore, why should credit unions be penalized if banks do not invest in lowering these agency costs? The second issue concerning risk structure is for credit union managers to change the asset composition of their loan portfolio by rapidly switching the business lines from high risk personal or business loans into lower risk mortgage loans, or by holding higher levels of cash deposits. We note the following arguments against such a strategy. First, it is costly to achieve this

\footnotetext{
${ }^{5}$ Personal loans accounted for an average of $80 \%$ for large and $90 \%$ for small credit unions during the research period.
} 
in the short run. It takes considerable time and resources to refocus the balance sheet, and realignment too quickly into non-traditional areas can be inefficient [Dahl and Spivey (1995), Brewer, Jackson and Mondschean (1996)]. For example, Wolken and Navratil (1981) examined the impact of the federal credit union usury ceiling on consumer credit availability and reported that credit unions lost business in the market for deposits as a result of changing their operations. In addition, Brewer, Jackson and Mondschean (1996) showed that in the face of regulation affecting portfolio risk levels, savings and loan institutions that diversified into non-traditional assets increased rather than reduced their risk exposure. The third issue relates to the loan portfolio that credit unions service. To rapidly turn aside from the high return personal loan area where credit unions have a comparative advantage in agency monitoring is an inefficient reallocation of resources and, arguably, and arguably, not in the interests of current credit union members. Moreover, the abrupt withdrawal of credit unions from the personal loans business would increase the cost of personal borrowing for society-at-large. Thus in summary, whilst the role of capital adequacy requirements in constraining the portfolio risk of profit maximising institutions, such as banks, is perceived to be beneficial, it is not clear whether the same argument can be applied to cooperative institutions.

Taking another tack, the theoretical postulates of Fudenberg and Tirole (1995) and the empirical research by Ahmed, Lobo and Zhou (2000) and Kanagaretnam, Lobo and Mathieu (2003) predicts that managerial entrenchment provides a strong motivation to undertake risky accounting window dressing when under threat. As a group, and relative to similar positions in the financial sector, it may be argued that credit union managers have captured an influential power base and higher salaries and perquisites based on size [Davis (1994)], and therefore they have a strong incentive to minimise the risk of institutional failure in order to maintain this supernormal stream of salary and perquisites. Whilst these window dressings are risky, Bishop and Lys (2001) propose that the expected costs of regulatory violation are larger than the reputation costs of censure from the regulators.

Therefore, there were several theoretical reasons why credit union managers would window dress risk weighted capital in order to meet minimum requirements. In summary, the risk weightings on personal loans were incorrect, it was not within the cooperative charter to rapidly withdraw customers' access to personal loans, and managers had a personal interest in maintaining the credit union as a going concern. Based upon these considerations our second hypothesis is: 
H2A: At-risk credit union managers will aggressively use accounting window dressing in order to meet minimum capital adequacy requirements with regard to risk-weighted capital.

H2B: These manipulations will be short term in nature and will be used to buy time in order to implement more gradual change policies to lower loan book risk.

\section{Data and Summary Statistics}

The data was manually sourced from the Registrar of New South Wales (NSW) cooperative societies and consists of summary accounting data that is lodged with the Registrar each quarteryear. The initial data set consists of a sample of one hundred and thirty-seven credit unions out of the full sample of one hundred and forty-four NSW credit unions, ${ }^{6}$ is representative of almost half of the two hundred and eighty-eight credit unions in operation in Australia at the time of AFIC. The sample period covers thirty-one quarterly reporting periods from June 1987 through to December 1994. From this data we construct a quarterly return on assets ratio by dividing operating earnings before tax by total assets (QROA). This return on asset ratio is generally used in the banking literature as a measure of efficiency and therefore we use abnormal changes in this measure, explained later, as an indicator of increases and decreases in operating efficiency.

We than utilize a second ratio that specifically applies to the risk weighting of assets as defined by AFIC. We first break down total assets, obtained from the quarterly financial reports of all credit unions, into the designated AFIC risk classes. These assets were then weighted by the AFIC risk weighted ratios in order to estimate the total risk weighted assets (RWA). The quarterly risk adjusted capital adequacy ratio (QCAR) was then calculated according to the principles outlined in footnote 6 as follows:

$$
Q C A R=\frac{T_{1} K+T_{2} K}{R W A}
$$

where $T_{1} \mathrm{~K}$ is tier one capital, $T_{2} \mathrm{~K}$ is tier two capital and $R W A$ is risk weighted assets. The $\triangle Q C A R_{t}$ was then calculated from first differences.

Following Kim and Kross (1998), we then determined those credit unions that were deemed to be at-risk and more likely to engage in earnings and risk capital accounting management

\footnotetext{
${ }^{6}$ Seven credit unions were omitted because of incomplete financial data sets.
} 
techniques. AFIC required a minimum of $8 \%$ risk adjusted capital and this legislation was operative from the September 1992 reporting quarter. At-risk credit unions were defined to be those whose risk-adjusted capital was lower than the required $8 \%$ threshold one year before the enactment date, 30 June 1991. We then obtained all 31 quarterly financial reports over the research period and proceeded to decompose total assets into the various risk classes in order to calculate the CAR per equation (1) for each quarter. The at-risk credit unions were then stratified according to size, where small (large) credit unions are defined as having total assets less than (greater than) A \$20 million as at 30 June 1992. We isolated sixteen (16) large and sixteen (16) small at-risk credit unions. ${ }^{7}$

The size decomposition was undertaken for two reasons. First, the research of Fried, Knox Lovell and Vanden Eeckaut (1993) suggests that the financial performance of credit unions is related to size, since size influences asset structure (especially the extent of diversification of the loan portfolio), and the ability to quickly generate profits. A second reason is the view that size acts as a proxy for the strength of the financial agency relationship between directors along with the possible gains from economies of scale from size [Esho (2000)]. It is therefore possible that large credit unions have a more developed governance structure and generally increased financial accountability. ${ }^{8}$

\section{Statistical Model and Results}

\subsection{Statistical Model}

As a preliminary analysis, Figure 1 provides a visual indication of $Q R O A_{t}$ and $\triangle Q C A R_{t}$ for large and small 'at-risk' credit unions over the research period. It can be clearly seen that $\triangle Q C A R_{t}$ increased dramatically around the quarter that AFIC was introduced, while $Q R O A_{t}$ changed very little. To provide some statistical robustness to this visual observation we estimate a polynomial lag model to capture the time series impact of the introduction of AFIC $\left(\varpi_{i}\right)$ alternatively on $Q R O A_{t}$ and $\triangle Q C A R_{t}\left(\right.$ denoted by $\left.Y_{t}\right)$.

\footnotetext{
${ }^{7}$ Average assets were $\$ 68$ million for large and $\$ 6.4$ million for small credit unions and small credit unions had a higher quarterly return on assets than large credit unions $(37.58 \% \mathrm{v} 35.51 \%)$ and a higher percentage of risky assets (personal loans compared to total loans $93 \%$ v $85 \%$ ).

${ }^{8}$ Hautalvoma et al. (1993) report that the degree of financial governance of chief executive officers (CEO) was positively related to size.
} 


$$
Y_{t}=\mu_{t}+\phi_{j} \sum_{j=1}^{4} Y_{t-j}+\frac{\varpi_{i}}{1-\delta_{i, 1} B-\cdots-\delta_{i, r} B^{r}} A F I C+\varepsilon_{t}
$$

where $\mu_{\mathrm{t}}$ is a constant, $j$ is the order of an autoregressive time-series process on $Y_{t}$, and $\varepsilon$ is the uncorrelated noise term zero with mean zero and a normal distribution. The intercept and the timeseries component are thus a measure of the expected value of $Q R O A_{t}$ and $\triangle Q C A R_{t}$ that capture a constant and the impact of all quarters lagged back one-year to capture any seasonal component. That is they estimate the ratios that would be observed in the absence of any regulatory interventions.

The remaining term centered on $\varpi$ now becomes the important variable for our research because it measures the excess impact over and above the expected components labeled the abnormal component. First, it comprises the numerator $\varpi_{i}$ as an intervention function that measures the contemporaneous impact of AFIC in the September 1992 quarter. If $\varpi_{i}$ is not significant then there is no impact from the introduction of AFIC. The denominator measures longevity of the impact, where $B$ is the backward operator that has an $r$ order of the response function that measures the length of the impact of AFIC on $Y_{t}$, and $\delta_{i}$ estimates the strength of the mean-reversion effect of AFIC. The coefficient $\delta_{i}$ is therefore particularly important as it measures the permanence of the impact of AFIC. If $\delta_{i}$ lies in the range $\left(0<\delta_{i}<1\right)$ then the regulatory impact initially results in a spiked jump and has a reversion effect in the following form:

$$
\left[1+\delta B^{1}+\delta^{2} B^{2}+\ldots+\delta^{r} B^{r}\right] \varpi
$$

If $\delta_{i}$ is close to or equal to zero then it has little or no long term impact but the closer $\delta$ is to one and if $r$ is large then the impact will be long term (see Box and Jenkins 1976, Ch.11). Thus the size of the spike $\varpi$ and the reversion effect provides evidence of both the initial impact as well as longevity of the AFIC regulation on profitability and the aggressiveness of the accounting manipulations.

\subsection{Results on Operating Profitability}

Our first hypothesis predicts that credit union managers will not implement policies designed to increase operating efficiency and increase raw profitability in order to minimum capital adequacy requirements. Table 2 provides the statistical results for the QROA analysis for both large and small 'at-risk' credit unions. For large credit unions, there is no evidence of any abnormal increase in raw 
profitability after AFIC, as $\varpi$ is not significant. However, there is evidence of an increase in efficiency for small at-risk credit unions with profitability gains around $\left(\varpi_{1}=0.21\right)$ but with only limited impact one period afterwards $\left(\delta_{1}=0.187\right)$. In order to compare the results of the 'at-risk' credit unions we ran the same model for the 'not at-risk' credit unions. The time series components were similar and the intercept for large credit unions was 0.3562 compared to 0.3415 for large atrisk thus indicating similar operating margins and no change. On the other hand, small 'not-at-risk' credit unions experienced significantly lower QROA's within a 2-year window after AFIC. ${ }^{9}$ Further, the intercept for all small credit unions was 0.3867 compared to 0.2941 for at-risk credit unions indicating that there was some efficiency slack available to small 'at-risk' credit unions.

In terms of our first hypothesis, we conclude that $\mathrm{H} 1$ is supported for large at-risk credit unions, but for small at-risk credit unions there is weak evidence that they increased profitability for a short period around AFIC. However, further analysis shows there was a drop in average profitability for all small credit unions after AFIC suggesting that for the majority the introduction of AFIC was not related to efficiency gains.

\subsection{Results on Changes in the Capital Adequacy Ratio}

Our next test makes use of the $\triangle \mathrm{QCAR}$ measure which results from applying the AFIC risk weightings to the asset structure and is a measure of all the components required to meet the minimum capital adequacy ratio. The statistical results are reported in Table 3 and they reveal significant and positive spikes in the change in the capital adequacy ratios during the September 1992 quarter for both large and small at-risk credit unions. Large credit unions had a significantly higher jump in CAR (2.81\%) compared to a smaller spike for small credit unions $(1.23 \%)$. But small credit unions had a comparatively longer evolution of their risk weighted capital as it continued to increase by $1.61 \%$ above the expected time-series for the three quarters from September 1992 to March 1993. ${ }^{10}$ The higher spike for larger credit unions and a slower reversion of the change in risk-weighted capital for smaller credit unions also suggests a more aggressive approach by larger

\footnotetext{
${ }^{9}$ Results not reported but available on request. It may be possible that the AFIC legislation imposed substantial costs and the subsequent force majeure lead to the diversification of small credit unions into inefficient operating areas away from the personal loan area [Brewer, Jackson and Mondschean (1996) and Wolken and Navratil 1981].

${ }^{10}$ Derived from the functional form of equation (3) and the results in Table 3B.
} 
credit unions. These statistical characteristics are also clearly observed in the time-series plots in Figures 1 and 2 which show the unusual nature of the $\triangle \mathrm{QCAR}$ around the introduction of increased capital adequacy requirements. For both small and large credit unions, the $\triangle \mathrm{QCAR}$ plots below QROA, except around the imposition of increased AFIC capital adequacy requirements during the September quarter 1992.

Thus, based upon our statistical and visual analysis, there were significant and unusual increases in the capital adequacy ratio of at-risk credit unions around the enactment of AFIC and this provides preliminary support for hypothesis $2 \mathrm{~A}$. In the next section, we turn to an investigation of how the $\triangle \mathrm{QCAR}$ was increased by credit union managers by examining several scenarios.

\subsection{Results on Accounting Window Dressing}

In order to assess whether any window dressing using accounting management occurred, we first require an expectations model that measures expected $\triangle \mathrm{QCAR}$ for each individual at-risk credit union. We do so by using panel models to estimate a fixed intercept and time-series for each credit union (i) as follows:

$$
E\left[\Delta Q C A R_{t, i}\right]=\mu_{t, i}+\sum_{j=1}^{4} \phi_{i} \Delta Q C A R_{t-j}
$$

We then subtract actual $\triangle \mathrm{QCAR}$ from $\mathrm{E}[\Delta \mathrm{QCAR}]$ to derive unexpected $\triangle \mathrm{QCAR}$ for all quarterly periods in 1992. That is, we constrain each credit union to have a common intercept in each period and allow the time-series coefficients to vary across individual credit unions. ${ }^{11}$

We then propose several techniques that managers may use to manage the upward change in risk weighted capital through accounting techniques. The first is discretionary accounting adjustments used to lower expenses. We take bad debt expense divided by the change in loans, and long service and holiday leave expense both divided through by salary expense, and rerun equation (4) for to calculate expected expenses for each credit union. From expected and actual expenses we then calculate unexpected $\triangle \mathrm{QCAR}$ as a measure of management window dressing. The second technique is dirty surplus accounting whereby any adjustments are taken directly to equity rather than adjusted through the income statement. For example adjustment in loan loss provisions or asset

\footnotetext{
${ }^{11}$ By using this technique we assume that there are common industry characteristics that determine the average QCAR (and individual expenses), but each credit union has a different time series determined by growth and
} 
revaluations taken directly to reserves are isolated and reversed in all individual credit union accounts. Finally, the third technique is to reclassify assets into a lower risk class in order to lower the impact of the denominator on the calculation of risk weighted capital. To calculate this impact, unexpected risk adjusted assets are calculated using equation (4). The impact of these three techniques are then summed and compared to the unexpected change in risk weighted capital for each credit union. We then repeat this procedure for all firms in all the 1992 quarters and then sum and average the results for both small and large at-risk credit unions.

Results are reported in Table 4 and they show that the reclassification of loans to reduce the risk weighting of assets was the most utilized accounting technique to window dress the capital adequacy ratio. This was used by all sixteen of the large credit unions and by nine of the small credit unions. Large credit unions had a 26\% higher net effect from accounting window dressing when compared to small credit unions and all asset risk re-classifiers had risk-adjusted capital above $8 \%$ by the end of December 1992. In addition to loan asset reclassifications, seven of the sixteen large credit unions used 'dirty surplus' and/or discretionary income manipulative accounting methods to increase equity and further boost their risk-adjusted capital. A higher proportion of small credit unions (15 of 16) applied such techniques. Overall, reclassifications contributed 97\% of the unexplained changes in the risk-weighted capital adequacy ratio for large credit unions compared to $39.8 \%$ for small credit unions. Small credit unions relied to a greater extent on dirty surplus and discretionary accounting (30.3\% compared to $8.1 \%)$.

In summary, our analysis indicates that during the 12-month window immediately surrounding the introduction of the AFIC legislation, at-risk credit unions employed accounting strategies to reduce the threat of being placed under 'direction'. The most frequently applied strategy was the aggressive reclassification of loans from high-risk personal/business loans to lowerrisk housing loans. The above affirms that credit unions used a variety of accounting window dressing techniques and they were aggressive providing further support for $\mathrm{H} 2 \mathrm{~A}$ and partial support for $\mathrm{H} 2 \mathrm{~B}$.

\subsection{Later Developments}

We now turn to an evaluation of the longer time series events that impacted on credit union operations by examining the subsequent merger activity of the credit unions deemed at risk and

accounting policies. 
examine changes in loan operations. The intention is to shed more light on whether the accounting manipulations lead to ultimate sanction (indicating opportunistic intentions) or that managers simply bought more time to adjust operations in a more measured fashion. Of the full data set of 137 credit unions $64(46.7 \%)$ were subsequently merged over the following twelve year period. In comparison 12 of the $32(37.5 \%)$ at-risk credit unions were merged. Taking a shorter term view over the following three years, $12(8.8 \%)$ of all credit unions were merged and $6(18.8 \%)$ of at-risk merged. With regard to changing operations, by observing Figure 3 we observe that credit unions slowly changed their risk profile over time towards housing loans and away from personal consumer loans. This analysis suggests that if at-risk credit union managers were able to delay the threat of merger long enough to manage their change in operations then they would be better than average survivors in the long run supporting $\mathrm{H} 2 \mathrm{~B}$.

\section{Summary and Discussion}

This study analyses the impact of the increased capital adequacy requirements on cooperative credit unions as imposed by the Australian Financial Institutions Code (AFIC) in July 1992. In essence, the prime accounting ratio directive of AFIC required a minimum of $8 \%$ capital as a ratio of risk adjusted assets, which was an abrupt and controversial increase from the $3 \%$ previously required by the NSW legislation. We found that capital adequacy levels moved quickly to satisfy the risk weighted capital requirements as laid down by AFIC. However, the process by which capital adequacy levels changed was not via increased operating profitability but through accounting window dressing mainly in the form of asset reclassifications.

This paper makes several contributions and raises several issues of an ethical nature. First, it isolates a situation whereby managers have very limited ability to meet risk-capital standards in order to reduce potential transaction, monitoring and personal costs and where the legislation possibly has the power to change the fundamental operating philosophy. Second, it highlights the importance of both external and internal governance as an indicator of potential accounting manipulations. Third, we raise ethical considerations on credit union managers reactions to abrupt template banking regulation.

The first issue is whether it is ethical to impose template external regulation on institutions far removed from the original purpose. There was evidence of some previous failures of credit 
unions (these failures were controlled and managed by the industry itself) and internal agency relations and governance in credit unions is weak. Hence, on the face of it there could be an argument for external intervention to mitigate these internal problems via international 'best practice'. But what is best practice for large international corporations may not be the case for small cooperatives. First, they are not homogenous with regard to operations and cultural philosophy. There is wide evidence that credit unions have lower agency costs in managing personal debt and hence the risk adjustments imposed by AFIC are not representative of the underlying risks that credit unions bear. Second, the risk weightings provide regulatory incentives to diversify into lower risk activities. Small cooperatives may not have the expertise or the staff to undertake such activities and therefore the (un)intended result was a rash of mergers in order to fulfill the regulatory requirements. This was a fundamental change in operations that moved the focus away from the social externality of providing credit in the form of personal unsecured loans (difficult to obtain from banks and significantly less expensive than other financial institution sources) and their comparative advantage obtained from lower individual agency search costs [Kohers and Mullis (1987)]. Hence, a long term consequence was a change in fundamental operations caused by a slow move towards housing loans to a ratio close to $70 \%$. In effect, moving credit unions to mirror the loan book of banks.

The second ethical consideration issue is the use of window dressing by managers. The first question is who, if anyone was adversely affected by the window dressing? There were no collapses of credit unions after AFIC, so society at large was not affected. On the other hand, by using accounting window dressing it can be concluded that managers bought time so that credit unions could maintain the current cooperative charter of their operations and to slowly move towards meeting AFIC risk-capital requirements. We therefore argue that it was an ethical response and well within the duty of managers to undertake actions that circumvented inappropriate template regulation. Regardless, a major beneficiary of the window dressing could be argued to be entrenched credit union managers. Subsequent, evidence is that at-risk credit union mergers was, overall, no higher than credit unions at large and the majority impact was to allow credit unions to manage their adjustment. Further, given the extreme comparative salaries in the banking sector we conclude that this was not a strong driver of this behaviour.

In summary, this case study outlines factors that inexorably gave rise to a strong motive to 
window dress by using aggressive accounting manipulations and establishes a link between accounting manipulations and internal and external corporate governance. Whilst raising several ethical issues with regard to accounting manipulations it also highlights the complex nature of imposing template regulations across whole industries. The question then is whether this is pseudo regulation or pseudo compliance? The answer is both.

It is also a strong possibility that the window dressing was known to the regulatory authorities who took into account the circumstances and moral force of these actions. ${ }^{12}$ This raises some policy implications. Regulatory bodies can make more efficient policies if they understand that corporations are not homogenous with regard to internal corporate governance and operating philosophies, and consider the impact of regulations on managerial incentives and behaviour. An understanding of the different philosophy and culture of organisations can also guard against the issuance of template regulations that may be inequitable in their impact and, hence, even require accounting manipulators to save the day for the firm.

\footnotetext{
${ }^{12}$ Anecdotal evidence from private conversations.
} 


\section{References}

Ahmed, A. S., Lobo, G. J., Zhou, J., 2000. Job Security and Income Smoothing: An Empirical Test of the Fudenberg and Tirole (1995) Model, SSRN October. http://ssrn.com/abstract=248288

Ahmed, A.S., Takeda, C., Thomas, S., 1999. Bank loan loss provisions: A re-examination of capital management, earnings management and signaling effects. Journal of Accounting and Economics $28,1-25$.

Allred, A.T. 2001, Employee evaluations of service quality at banks and credit unions, International Journal of Bank Management, 19, 4, 179-185.

Allred, A.T. and H. L. Adams. 2000, Service quality at banks and credit unions: What do their customers say?, Managing Service Quality, 10, 1, 52-60.

Beatty, A., Chamberlain, S.L., Magliolo, J., 1995. Managing financial reports of commercial banks: The influence of taxes, regulatory capital and earnings. Journal of Accounting Research 33, 231262.

Berle, A., Means, G., 1932. The modern corporation and private property. Macmillan, New York.

Bishop, M., Lys, T., 2000. Inferring accounting information from corporate financing choices: An examination of security issuances in the banking industry, University of Pennsylvania, Working Paper.

Box G.E.P, Jenkins, G.M., 1976. Time series analysis: Forecasting and control. Holden-Day, San Francisco.

Brewer, E., Jackson, W.E., Mondschean, T., 1996. Risk, regulation, and S \& L diversification into nontraditional assets. Journal of Banking and Finance 20, 723-744.

Collins, J., Shackelford, D., Whalen, J., 1995. The co-ordination of regulatory capital, earnings, and taxes for banks. Journal of Accounting Research 33, 263-292.

Colgate, M. and B. Lang, 2005. Positive and negative consequences of a relationship manager strategy: New Zealand banks and their small business customers. Journal of Business Research, 58: 195-204.

Cook, D.O., Hogan A., Kieschnick, R., 2004. A study of the corporate governance of thrifts. Journal of Banking and Finance 28, 1247-1271.

Dahl, D., Spivey, M.F., 1995. Prompt corrective action and bank efforts to recover from undercapitalization. Journal of Banking and Finance 19, 225-243.

Davis, K., 1994. Prudential regulation and Australian credit unions. Australian Journal of Management 19, 31-46.

Davis, K., 2001. Credit union governance and survival of the cooperative form. Journal of Financial Services Research 19, 197-210.

Dechow, P.M., Sloan, R.G., Sweeney, A.P., 1996, Causes and consequences of earnings manipulations: An analysis of firms subject to enforcement actions by the SEC, Contemporary Accounting Research, 13, 1, 1-36.

Duncan, E. and G. Elliot, 2002. Customer service quality and financial performance among Australian retail financial institutions. Journal of Financial Services Marketing, 25-41.

Esho, N., 2000. Scale economies in credit unions: Accounting for subsidies is important. Journal of Financial Services Research 18, 29-43.

Fama, E.F. and Jensen, M.C. 1983. Agency problems and residual claims, Journal of Law and Economics, 26, 327-349.

Frame, W.S., Karels, G.V., McClatchey, C., 2002. The effect of the common bond and membership expension on credit union risk. The Financial Review 37, 613-636.

Frame, W.S., Karels, G.V., McClatchey, C., 2003. Do credit unions use their tax advantage to benefit members? Evidence from a cost function. Review of Financial Economics 12, 35-47.

Fried, H.O., Knox Lovell, C.A., Vanden Eeckaut, P., 1993. Evaluating the performance of US credit unions. Journal of Banking and Finance 17, 251-265.

Fudenberg, K., Tirole, J., 1995. A theory of income and dividend smoothing based on incumbency rents. Journal of Political Economy 103, 75-93.

Goldsworthy, B., Schulz, C., Shuetrim, G., 2000. Capital management of deposit takers: The impact of prudential requirements. Australian Prudential Regulatory Authority Working Paper.

Hautalvoma, J.E., Jobe, L., Donkersgoed, B., Suri, T., Cropanzano, R., 1993. Credit union boards and credit union effectiveness. Filene Research Institute Centre for Credit Union Research, Wisconsin.

Healy, P.M., Wahlen, J., 1999. A Review of the earnings management literature and its implication 
for standards setting. Accounting Horizons 13, 365-383.

Jensen, M.C., Meckling, W.H., 1976. Theory of the firm: Managerial behavior, agency costs and ownership structure. Journal of Financial Economics 3, 305-360.

Kanagaretnam, K., G.J. Lobo and R. Mathieu, 2003. Managerial Incentives for Income Smoothing through Bank Loan Loss Provisions. Review of Quantitative Finance \& Accounting, 20, 1, 6380.

Keasey, K., Thompson, S., Wright, M., 2005. Corporate governance: accountability, enterprise and international comparisons. Wiley, pp 2-3.

Kim, M-S., Kross, W., 1998. The impact of the 1989 change in bank capital standards on loan loss provisions and loan write-offs. Journal of Accounting and Economics 25, 69-99.

Kohers, T., Mullis, D., 1987. The impact of credit union company business on borrower-saver treatment. Review of Business and Economic Research 23, 38-49.

Rosen, R.E., 2003, Risk management and corporate governance: The case of Enron. Connecticut Law Review 35, 1157-1184.

Smith, D.J., 1984. A theoretical framework for the analysis of credit union decision making. Journal of Finance 39, 1155-1168.

Smith, D.J., 1988. Credit union rate and earnings retention decisions under uncertainty and taxation. Journal of Money Credit and Banking 29, 119-131.

Smith, D.J., Cargill, T.F., Meyer, R.A., 1980. An economic theory of a credit union. Journal of Finance 36, 519-528.

Wolken, J.D., Navratil, F.J., 1981. The economic impact of the federal credit union usury ceiling. The Journal of Finance 36, 1157-1168. 
Table 1: Asset Risk Weightings and Capital Adequacy Requirements Imposed by the July 1992 AFIC Regulations on Credit Unions

AFIC regulations require institutions to hold a minimum of $8 \%$ capital as a ratio of risk-adjusted assets, $7 \%$ of assets as prime liquid assets and $8 \%$ of assets to be held as operational liquidity. The $8 \%$ risk-adjusted capital must comprise a minimum of $4 \%$ Tier 1 capital (equity, retained earnings, preferred capital). The remainder can be made up of Tier 2 capital (loan loss provisions (LLP), perpetual preferred stock and debt, convertible debt and other subordinated stock and debt) of which there can only be a maximum of $1.25 \%$ of LLP. In addition, market, credit, data and operations risk are required to be managed and reported together with the provision of guarantees and management contracts in managed funds. AFIC requires that credit union assets be divided into five categories, each of which is assigned a specific risk weighting given below. Total riskweighted assets are then derived by multiplying the dollar value of all assets by their risk weight and then summing.

\section{Risk Weight \%}

0

10

20

50

$\underline{100}$
Type of Asset

Notes, coin and short-term federal government debt

Long-term federal government debt, state government debt

Bank liabilities, local government debt

Residential mortgage loans

Unsecured business loans, personal loans, lines of credit 
Table 2: The Impact of AFIC on the Quarterly Return on Assets of 'At-Risk' Credit Unions

Sample consists of 16 large and 16 small credit unions whose capital adequacy ratio was below $8 \%$ one year before AFIC (31 June 1991).

Model is : $\mathrm{QROA}_{t}=\mu_{t}+\frac{\varpi_{i}}{1-\delta_{i, 1} B-\cdots-\delta_{i, r} B^{r}}$ AFIC $+\sum_{j=1}^{4} \phi_{j} Q_{t-j}$

The model was estimated simultaneously by maximum likelihood via nonlinear least squares. The adequacy of the fitted model was determined by checking the statistical significance of the coefficients and performing diagnostic checks on the residuals. Competing models were compared and chosen using the Akaike Information Criterion (AIC) and Schwartz Bayesian Criterion (SBC). *Denotes statistical significance at the $5 \%$ level; and ** denotes statistical significance at the $10 \%$ level.

Panel A: Large 'At-Risk' Credit Unions

\begin{tabular}{|c|c|c|c|l|}
\hline \hline & Coefficient & Estimate & T Ratio & \multicolumn{2}{|l|}{ Variable } \\
\hline 1 & $\mu$ & 0.3415 & $10.86^{*}$ & Constant QROA \\
2 & $\phi_{1}$ & 0.5239 & $12.52^{*}$ & QROA lag 1 period \\
3 & $\phi_{2}$ & 0.2000 & $4.77^{*}$ & QROA lag 4 periods \\
\hline \multicolumn{2}{|c|}{ AIC -246.37 } & & SBC -226.21 \\
\hline
\end{tabular}

Panel B: Small 'At-Risk' Credit Unions

\begin{tabular}{|c|c|c|c|l|}
\hline \hline & Coefficient & Estimate & T Ratio & Variable \\
\hline 1 & $\mu$ & 0.2941 & $10.07^{*}$ & Constant QROA \\
2 & $\phi_{1}$ & 0.1883 & $3.87^{*}$ & QROA lag 1 period \\
3 & $\phi_{2}$ & 0.1068 & $2.19^{*}$ & QROA lag 3 periods \\
4 & $\omega_{1}$ & 0.2112 & $2.07^{*}$ & Impact of AFIC Sep Qtr 92 \\
5 & $\delta_{1}$ & 0.1868 & $1.80^{* *}$ & Reversion coefficient \\
\hline \multicolumn{2}{|r|}{} & AIC 426.35 & & SBC 450.47 \\
\hline
\end{tabular}




\section{Table 3: The Impact of AFIC on the Change in Quarterly Capital Adequacy Ratio of 'At-Risk’ Credit Unions}

Sample consists of 16 large and 16 small credit unions whose capital adequacy ratio was below $8 \%$ one year before AFIC (31 June 1991).

Model is : $\triangle Q C A R_{t}=\mu+\frac{w_{i}}{1-\delta_{i, 1} B-\cdots-\delta_{i, r} B^{r}} A F I C+\sum_{j=1}^{4} \phi_{j} \Delta Q C A R{ }_{t-j}$

The model was estimated simultaneously by maximum likelihood via nonlinear least squares. The adequacy of the fitted model was determined by checking the statistical significance of the coefficients and performing diagnostic checks on the residuals. Competing models were compared and chosen using the Akaike Information Criterion (AIC) and Schwartz Bayesian Criterion (SBC). Denotes statistical significance at the $5 \%$ level; ** denotes statistical significance at the $10 \%$ level; and ${ }^{\#}$ denotes significance of the mean reversion coefficient to two lags at the $10 \%$ level.

Panel A: Large 'At-Risk' Credit Unions

\begin{tabular}{|c|c|c|c|c|c|}
\hline & Coefficient & Estimate & T Ratio & \multicolumn{2}{|c|}{ Variable } \\
\hline 1 & $\mu$ & 0.1295 & $4.22 *$ & \multicolumn{2}{|c|}{ Constant } \\
\hline 2 & $\phi_{1}$ & 0.1775 & $3.65^{*}$ & \multicolumn{2}{|c|}{$\triangle Q C A R_{t}$ lag 1 period } \\
\hline 3 & $\varpi_{1}$ & 2.8099 & $22.71^{*}$ & \multicolumn{2}{|c|}{ Impact of AFIC Sep Qtr 92} \\
\hline & aike IC & \multicolumn{2}{|c|}{600.95} & Schwartz BC & 621.11 \\
\hline
\end{tabular}

Panel B: Small 'At-Risk’ Credit Unions

\begin{tabular}{|c|c|c|c|l|}
\hline \hline & Coefficient & Estimate & T Ratio & \multicolumn{2}{|l|}{ Variable } \\
\hline 1 & $\mu$ & 0.1712 & $3.81^{*}$ & Constant \\
2 & $\phi_{1}$ & 0.1005 & $2.00^{*}$ & $\Delta Q C A R_{t}$ lag 1 period \\
3 & $\varpi_{1}$ & 1.2259 & $6.29 *$ & Impact of AFIC Sep Qtr 92 \\
4 & $\delta_{2}$ & 0.2492 & $1.69^{\#}$ & Reversion Coefficient \\
\hline \multicolumn{2}{|c|}{ AIC 956.73 } & & SBC 972.80 \\
\hline
\end{tabular}


Table 4: The Impact of Accounting Manipulations on the Increase in Risk Weighted Capital Adequacy - Two Quarters Before and After AFIC

The window period includes the quarters ended March, June, September and December 1992. Total is the attributed percentage that accounting arbitrage explained of the deviation from the panel time-series expectations of $\triangle \mathrm{QCAR}$.

Large Credit Unions Small Credit Unions

\begin{tabular}{ccr} 
Average Impact & Type & Average Impact \\
\hline $97.0 \%$ & Reclassification of assets (RA) & $39.8 \%$ \\
$3.1 \%$ & Dirty surplus accounting (DS) & $9.0 \%$ \\
$5.0 \%$ & Discretionary accounting (DA) & $21.3 \%$ \\
\hline $105.1 \%$ & & $70.1 \%$
\end{tabular}


Figure 1 - Quarterly Return on Assets and Change in Capital Adequacy Ratio Large 'at-risk' Credit Unions

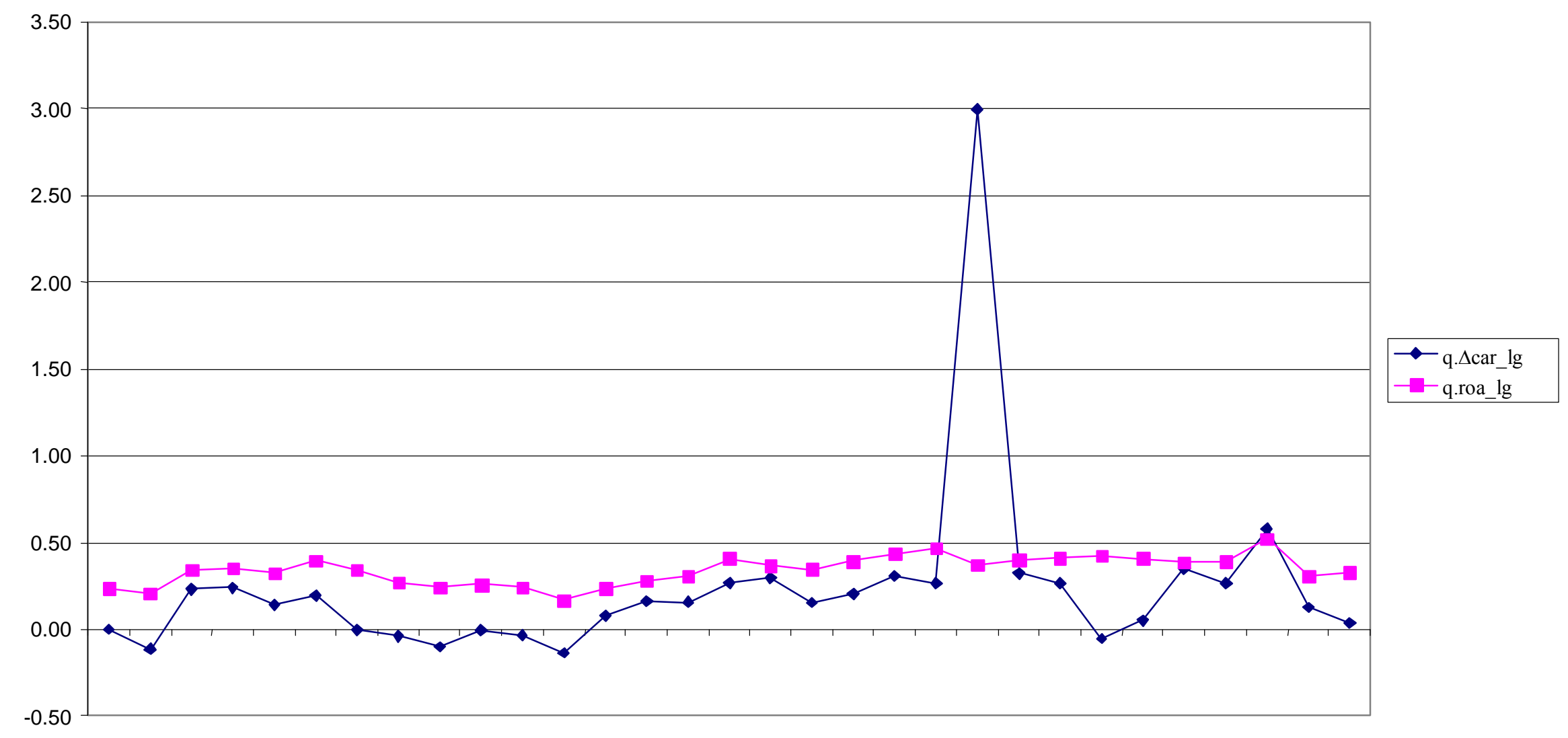

J87 S87 D87M88 J88 S88D88M89 J89 S89 D89M90 J90 S90 D90M91 J91 S91D91M92 J92 S92 D92M93 J93 S93D93M94 J94 S94D94 
Figure 2 - Quarterly Return on Assets and Change in Capital Adequacy Ratio Small 'at-risk' Credit Unions

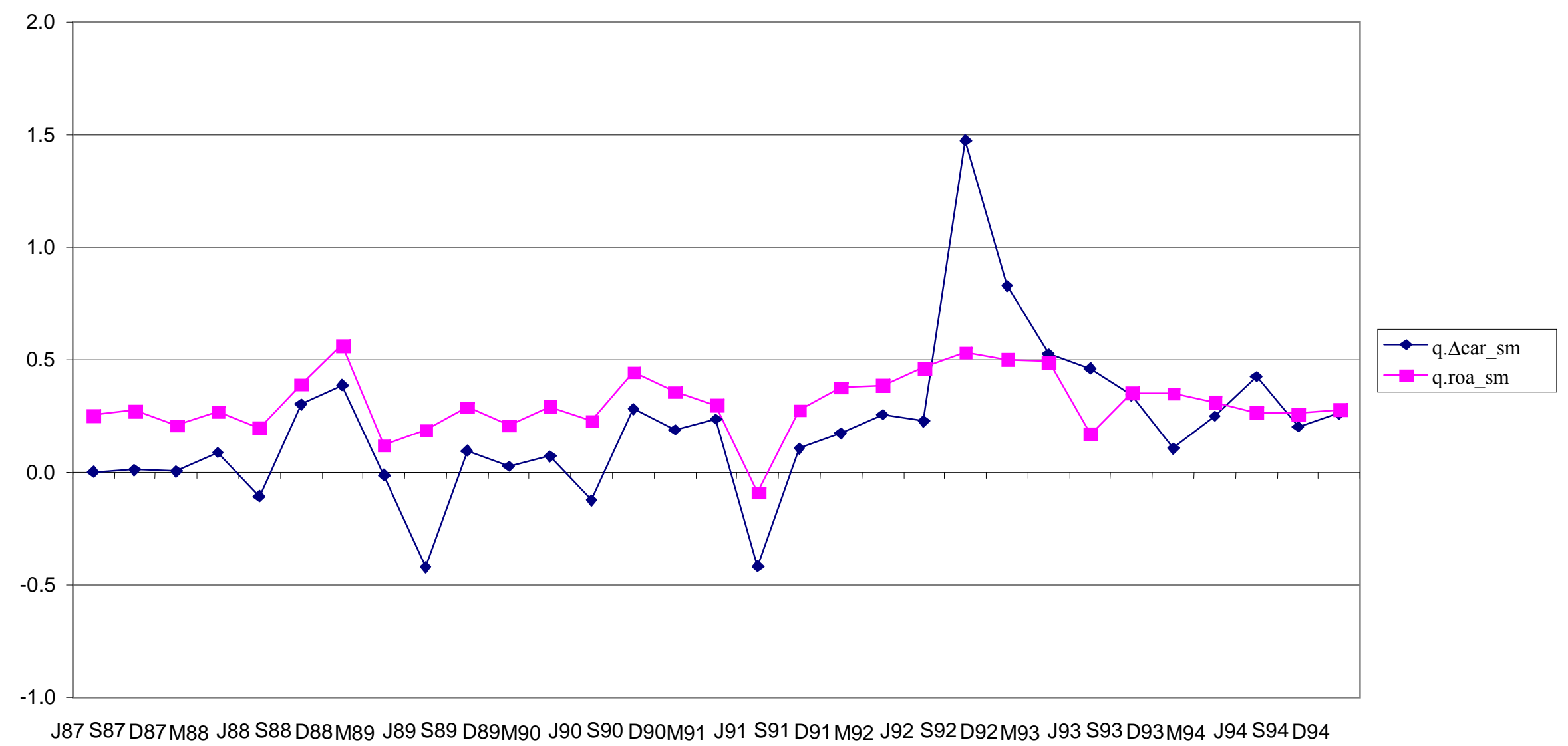


$\%$

100

$\infty$

80

ro

6

50

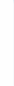

$\infty$

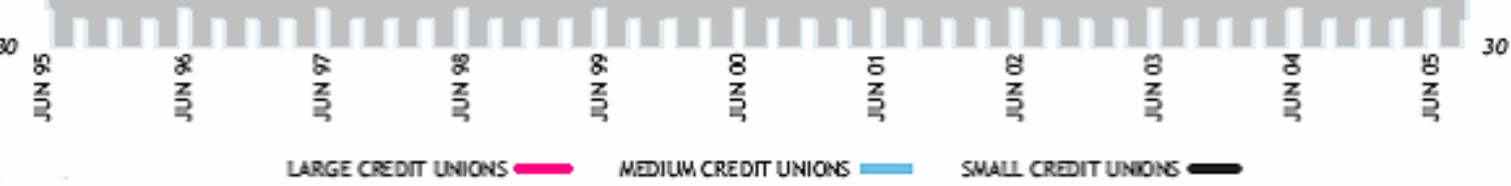

Source: Australian Prudential Regulatory Authority
Figure 3 - Housing Loans as a Percentage of Total Loans 